\title{
Anthropogenic Influence on Blood Biomarkers of Stress and Genotoxicity of the Burrowing Owl (Athene Cunicularia)
}

\author{
Martínez-Haro $\mathbf{M}^{1}$, Balderas-Plata $\mathrm{MA}^{2}$, Pereda-Solís $\mathrm{ME}^{3}$, Arellano-Aguilar $\mathrm{O}^{4}$, Hernández-Millán $\mathrm{CL}^{5}$, Mundo-Hernández V1 and \\ Torres-Bugarín $\mathbf{O}^{6^{*}}$ \\ ${ }^{1}$ Universidad Autónoma del estado de México, Paseo Colón s / $n$, Residencial Colón, State of Mexico, Mexico \\ 2Universidad Autónoma del Estado de México, Cerro de Coatepec $s / n$, Ciudad Universitaria, State of Mexico, Mexico \\ ${ }^{3}$ Universidad Juárez del Estaddo de Durango, Carretera Durango-Mezquital km. 11.5 Durango, Mexico \\ ${ }^{4}$ Universidad Nacional Autónoma de México, Av. Universidad 3000, exterior circuit s/n, university city, Coyoacan Delegation, City of Mexico, Mexico \\ ${ }^{5}$ Universidad Autónoma de Aguascalientes, Aguascalientes, Mexico \\ ${ }^{6}$ Laboratorio de Evaluación de Genotóxicos, Programa Internacional de Medicina, Universidad Autónoma de Guadalajara, Av. Patria 1201, Col. Lomas del Valle, Jalisco, \\ Mexico
}

\begin{abstract}
Anthropogenic activities are putting increasing pressure on ecosystems and raising the need to assess environmental health quickly and accurately. Heterophile/lymphocyte index is accepted as a response to stress factors and the micronucleus test is used as a biomarker to estimate genotoxic damage. To evaluate a model of environmental quality, healthy Burrowing owl (Athene cunicularia) were sampled, and the heterophile/lymphocyte ratio was determined, as well as the frequency of micronucleated erythrocytes and nuclear abnormalities, determined with the Wright-Giemsa and acridine orange technique. The sites with the greatest antropic disturbance recorded the highest frequencies of micronuclei and heterophile/lymphocyte index. The combination of both tests allows the detection of possible acute or chronic exposure to stressors and genotoxic contaminants, both in healthy or altered ecosystems.
\end{abstract}

Keywords: Aguascalientes; Biomonitoring; Heterophile; Lymphocyte; Micronucleus; Nuclear abnormality; Owl

\section{Introduction}

Anthropogenic activities modify ecosystems, mainly due to habitat degradation, loss and pollution [1,2], which exposes the wild populations to stressors and pollutants causing them become vulnerable. To asses these effects, the heterophile/lymphocyte index $(\mathrm{H} / \mathrm{L}$ index) was used as a measure of physiological response to immunosuppression and stress [3,4], caused by various etiological agents. A high H/L index consists of an increase in the frequency of heterophiles and a decrease in lymphocytes [5]. In the response to chronic stress, this index may be more useful and accessible than a single measurement of plasma corticosterone [6].

On the other hand, micronuclei can occur spontaneously, however, in the presence of certain endogenous or exogenous stresses $[7,8]$ the frequency of $\mathrm{MN}$ increases, becoming indicators of the effects of genotoxicity [9]. Micronuclei (MN) and nuclear abnormality (AN) frequency can be used as biomarkers to estimate genotoxic damage caused by physical, chemical or biological agents $[10,11]$. In addition, its low cost and relative ease, makes the MN test suitable the guideline to be considered as a routine technique in environmental monitoring studies.

The Burrowing Owl (Athene cunicularia hypugea: Sitrigidae) lives mainly in praire grasslands and open areas [12] of north America [13], which advantage the possibility of studying different spaces. It combines the ideal characteristics to be considered biomonitor of environmental genotoxics, is top depredator of small size, with superior clutches to three offspring per season [14]. They are territorial birds that facilitate their location, are sheltered in or stay near burrows and develop activities both day and night [15]. Additionally, its handling is relatively easy and it tolerates a certain degree of disturbance of anthropic origin. However, some basic parameters of biomarkers are not known to propose as a model. The aim of this study was to calculated the abundance and determine the values of heterophile/lymphocyte index and micronuclei of Burrowing owl from three sites with different degree of disturbance.

\section{Materials and Methods}

Sampling was carried out in the south and northeastern of the state of Aguascalientes, Mexico (Figure 1). Into township Aguascalientes, El Llano and Asientos with an average altitude of $2000 \mathrm{~m}$. The climate of the entity is semi-dry with an average annual temperature of $17.4^{\circ} \mathrm{C}$ and average rainfall of $526 \mathrm{~mm}$. The native vegetation is represented by oak forests in some high parts, grass (with the dominant genera of Aristida sp., Buchloe sp., Bouteloua sp. and Microchloa sp.) and different kind of xerophilous scrub characterized by cacti as nopaleras [16-18]. In the last decade the industrial and mining investment has increased in the entity, so that the natural habitat of the Burrowing owl has presented a drastic transformation in its use of soil.

During the period from October 2014 to July 2016, 16 transects on road were made in three sites, of 3.4 kilometers in average each one. Every 200 meters were made point-count with call playbacks, of two minutes of duration by one of silence, with three replicas. The observed and heard owls were recorded.

11 individuals of Burrowing Owl were captured with a trained Cooper Hawk (Accipiter cooperii), with protectors in the claws to avoid injury to the captured owls. A veterinarian clinically evaluated the health status of the birds, and biometric data (tarsus length and weight) were taken [19], each organism was classified as chick or adult according to

*Corresponding author: Torres-Bugarín Olivia $\mathrm{PhD}$. Laboratorio de Evaluación de Genotóxicos, Programa Internacional de Medicina, Universidad Autónoma de Guadalajara, Av. Patria 1201, Col. Lomas del Valle, Jalisco, Mexico, Tel: +52 33 3648 8824; E-mail: oliviatorres@hotmail.com

Received August 17, 2017; Accepted August 25, 2017; Published August 31 2017

Citation: Martínez-Haro M, Balderas-Plata MA, Pereda-Solís ME, ArellanoAguilar RO, Hernández-Millán CL, et al. (2017) Anthropogenic Influence on Blood Biomarkers of Stress and Genotoxicity of the Burrowing Owl (Athene Cunicularia). J Biodivers Endanger Species 5: 196. doi: 10.4172/2332-2543.1000196

Copyright: (c) 2017 Martínez-Haro M, et al. This is an open-access article distributed under the terms of the Creative Commons Attribution License, which permits unrestricted use, distribution, and reproduction in any medium, provided the original author and source are credited. 
Citation: Martínez-Haro M, Balderas-Plata MA, Pereda-Solís ME, Arellano-Aguilar RO, Hernández-Millán CL, et al. (2017) Anthropogenic Influence on Blood Biomarkers of Stress and Genotoxicity of the Burrowing Owl (Athene Cunicularia). J Biodivers Endanger Species 5: 196. doi: 10.4172/2332-2543.1000196

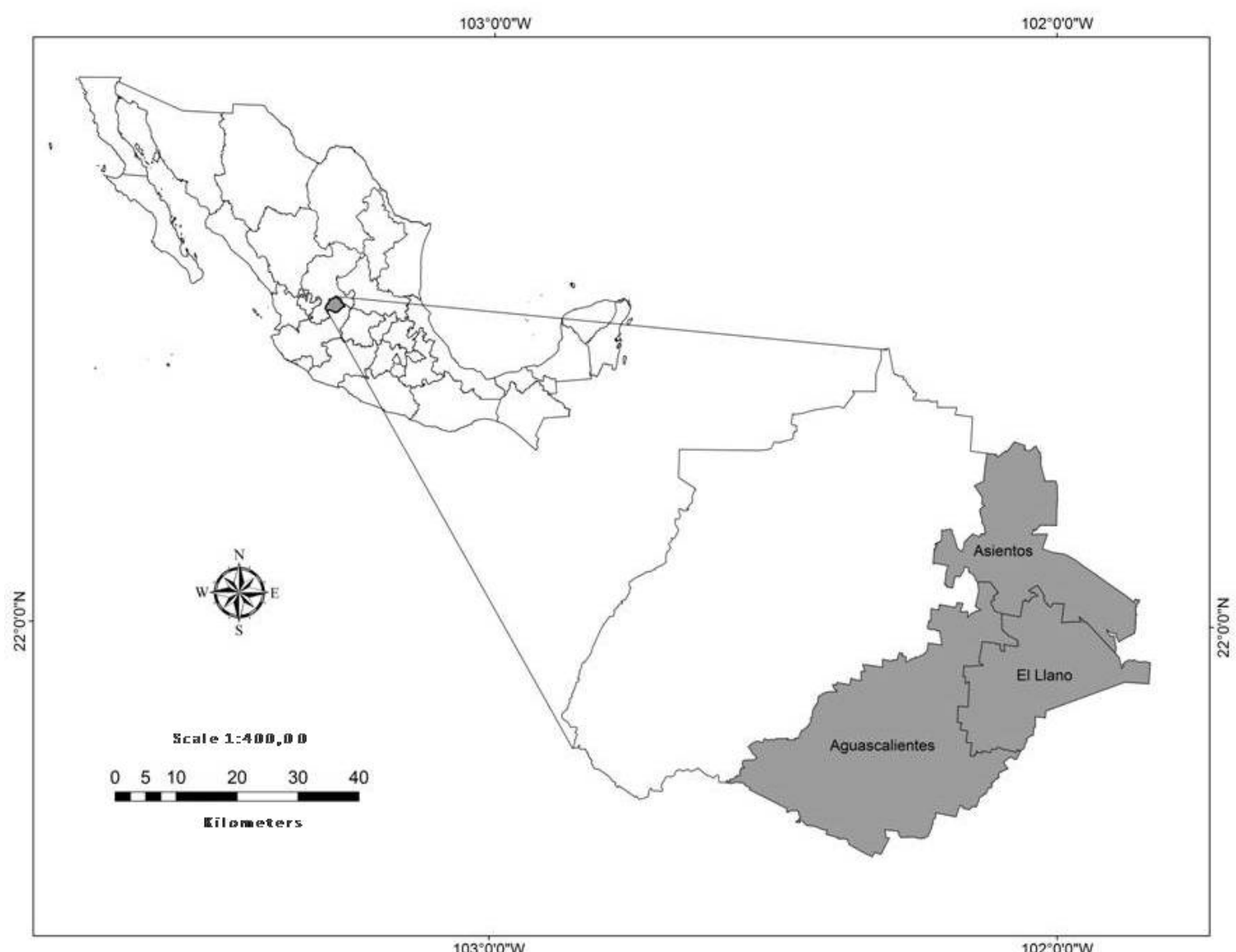

Figure 1: Sampling sites in the state of Aguascalientes, Mexico.

size, weight and plumage. After blood sampling (from the brachial vein, with a $25 \mathrm{G}$ needle and hypodermic syringe), the owls were banded as a form of identification and released immediately.

Two blood smears were performed per organism, one for micronucleus test $(\mathrm{MN})$ and other for the leukocyte differential. Both were fixed in ethanol (90\%), labeled and stored until were analyzed in the laboratory of International Program of Medicine, of Autonomous University of Guadalajara.

Smears intended for the micronucleus test were processed with the acridine orange technique. The frequency of MNE and NAE was counted in 10,000 total erythrocytes (TE) and the frequency of polychromatic erythrocytes (PCE) in 1000 erythrocytes. Also in 1000 PCE, the frequency of micronucleated PCEs (PCMNE) and PCE with nuclear abnormalities (PCNAE) was counted, trough of microscope equipped under the 100x objective (Zeiss, Axiostar plus model').

For differential leukocyte counts, the smears were stained with the Wrigth-Giemsa technique, 100 leukocyte cells were counted and the five types were identified: heterophiles, lymphocytes, monocytes, basophils and eosinophils, with the aid of immersion optic microscope (Zeiss, Axiostar plus model ${ }^{\circ}$ ). For calculate the heterophil/lymphocyte index $(\mathrm{H} / \mathrm{L})$, the number of heterophiles was divided by the number of lymphocytes from each smear [4].
Descriptive statistics (mean, standard deviation and ranges) of the micronucleated cells as well as the frequency of leukocytes, erythrocyte diameters, among others data were calculated. For calculate the abundance of burrowing owl, the average of the monthly records one was divided between the distances of transects in each township. In order to recognize the similarity between the monitored localities, the Bray-Curtis index was applied. The statistical analysis was performed using the software SPSS Statistics 20 (IBM Corp').

\section{Results and Discussion}

Owl abundance was low in the most disturbed sites (Asientos 0.15 and Aguascalientes 0.73 birds per $\mathrm{km}$ ), while the site of El Llano was 2.16 birds per $\mathrm{km}$, a locality in which there are grassland and xerophytic scrub patches (Table 1). The sites Aguascalientes and El Llano showed some degree of similarity (0.49).

It should be noted that the individuals captured, four were chicks which showed higher frequency of PCE (40.8 \pm 14.0$)$, MNPCE (22.2 \pm 13.8) and NAPCE $(6 \pm 8.1)$ than in adults. MNE was similar in chicks (7.8 $\pm 5.6)$ and adults $(6.6 \pm 7.0)$. However, the frequency of NAE, in adults it was higher $(25 \pm 15.8)$ than chicks (Table 2). The high values of EPC in the Burrowing owl chicks are due to the immature reticuloendoplasmic system, which is normal in birds at that age [11] and to constant activity in the production of blood cells, which will decrease until reaching the 
Citation: Martínez-Haro M, Balderas-Plata MA, Pereda-Solís ME, Arellano-Aguilar RO, Hernández-Millán CL, et al. (2017) Anthropogenic Influence on Blood Biomarkers of Stress and Genotoxicity of the Burrowing Owl (Athene Cunicularia). J Biodivers Endanger Species 5: 196. doi: $10.4172 / 2332-2543.1000196$

Page 3 of 4

homeostasis.

In the differential leukocyte count, lymphocytes were the most abundant in chicks (76.8 \pm 10.5$)$, followed by heterophiles $(11.3 \pm 6.0)$. In adults the same pattern was observed (lymphocytes $73.2 \pm 5.7$ and heterophiles $12.2 \pm 3.6)$. With regard to $\mathrm{H} / \mathrm{L}$ ratio, chicks recorded 0.16 \pm 0.09 and adults $0.17 \pm 0.06$ (Table 2).

High frequency of PCE in adult owls allows inferring, that during the environmental biomonitoring there are genotoxic agents that produce acute effects. The $\mathrm{MN}$ test together with $\mathrm{H} / \mathrm{L}$ index, enable to establish of immunological status and chronic exposure of pollutants; they are respond to different manifestations of the health state of the individuals and reflects the impact about the ecosystem, thus these parameters are a valuable tool in conservation efforts, thus providing early warning of potential damage to environment health, based on wildlife response [20,21].

In raptors from free life, observed that the elevated $\mathrm{H} / \mathrm{L}$ on individuals exposed to lead [22] and that a poor body condition promotes a high $\mathrm{H} / \mathrm{L}$ index, suggesting a decrease in immunocompetence or higher stress rates on the birds [23]. The weight and size recorded in the owls

\begin{tabular}{|c|c|c|c|}
\hline Biomarkers & Aguascalientes & El Llano & Asientos \\
\hline Abundance & 0.73 & 2.16 & 0.15 \\
\hline MNE/10000 & 10.0 & $6.7(6.3)$ & - \\
\hline NAE/10000 & 40.0 & $18.6(14.8)$ & - \\
\hline MNPCE/1000 & 0.0 & $1.7(2.5)$ & - \\
\hline NAPCE/1000 & 2.0 & $4.3(6.4)$ & - \\
\hline H/L ratio & 0.2 & $0.2(0.1)$ & - \\
\hline
\end{tabular}

Table 1: Abundance, frecuency of de micronucleus and $H / L$ ratio (mean \pm SD) registered in Burrowing Owl at each sampling site.

\begin{tabular}{|c|c|c|c|c|c|}
\hline \multirow{2}{*}{\multicolumn{2}{|c|}{ Parameter }} & \multicolumn{2}{|c|}{ Chicks (n=4) } & \multicolumn{2}{|c|}{ Adults $(n=7)$} \\
\hline & & $\begin{array}{l}\text { Mean ( } \pm \\
\text { SD) }\end{array}$ & Min-Max & $\begin{array}{c}\text { Mean ( } \pm \\
\text { SD) }\end{array}$ & Min-Max \\
\hline \multicolumn{2}{|c|}{ Tarsus long $(\mathrm{cm})$} & $36.8(1.4)$ & $35.2-38.3$ & $52.8(3.9)$ & $46.1-56.0$ \\
\hline \multicolumn{2}{|c|}{ Weight $(\mathrm{g})$} & $108.3(6.7)$ & $100-115$ & $\begin{array}{l}143.4 \\
(16.1)\end{array}$ & $120-160$ \\
\hline \multirow{5}{*}{$\begin{array}{c}\text { Leukocyte } \\
\text { differential } \\
\text { /100 leukocytes }\end{array}$} & Monocytes & $9.0(4.2)$ & $4-14$ & $9.5(2.7)$ & $6-14$ \\
\hline & Eosinophils & $2.5(0.6)$ & $2-3$ & $3.7(2.2)$ & $1-7$ \\
\hline & Basophils & $0.5(0.6)$ & $0-1$ & $1.5(1.4)$ & $0-4$ \\
\hline & Heterophiles & $11.3(6.0)$ & $3-17$ & $12.2(3.6)$ & $7-17$ \\
\hline & Lymphocytes & $76.8(10.5)$ & $66-91$ & $73.2(5.7)$ & $65-81$ \\
\hline $\mathrm{H} / \mathrm{L}$ ratio & & $0.16(0.09)$ & $0.03-0.3$ & $0.17(0.06)$ & $0.09-0.2$ \\
\hline \multicolumn{6}{|c|}{ Erythrocytes } \\
\hline \multirow[t]{2}{*}{ Cytoplasm } & Long $\mu \mathrm{m}$ & $14.8(0.2)$ & $14.6-15.0$ & $14.4(0.5)$ & $13.7-15.2$ \\
\hline & Wide $\mu \mathrm{m}$ & $8.7(0.6)$ & $8.1-9.2$ & $8.1(0.4)$ & $7.5-8.6$ \\
\hline \multirow[t]{2}{*}{ Nucleus } & Long $\mu \mathrm{m}$ & $5.9(0.1)$ & $5.8-6.0$ & $6 .-7(0.3)$ & $6.3-6.9$ \\
\hline & Wide $\mu \mathrm{m}$ & $3.3(0.1)$ & $3.6-3.4$ & $3.0(0.2)$ & $2.8-3.5$ \\
\hline $\mathrm{MNE} / 10,000 \mathrm{TE}$ & & $7.8(5.6)$ & $1-14$ & $6.6(7.0)$ & $0-20$ \\
\hline $\mathrm{NAE} / 10,000 \mathrm{TE}$ & & $12.8(13.2)$ & $2-32$ & $25(15.8)$ & $10-52$ \\
\hline PCE/1000 TE & & $40.8(14.0)$ & $25.1-58.9$ & $22.2(13.8)$ & $5.8-43.8$ \\
\hline $\begin{array}{l}\text { MNPCE } / 1000 \\
\text { PCE }\end{array}$ & & $3(3-6)$ & $0-8$ & $0.7(1.1)$ & $0-3$ \\
\hline $\begin{array}{l}\text { NAPCE/1000 } \\
\text { PCE }\end{array}$ & & $6(8.1)$ & $0-18$ & $3.0(5.1)$ & $0-14$ \\
\hline
\end{tabular}

H/L- Heterophil/Lymphocyte; MNE- Micronuclei erythrocytes; NAE- Nuclear abnormalities erythrocytes; TE- Total erythrocytes; PCE- Polychromatic erythrocytes; MNPCE- PCE with micronucleus; NAPCE- PCE with nuclear abnormalities.

Table 2: Frequency of erythrocytes with micronucleus and nuclear abnormalities, leukocyte differential and $\mathrm{H} / \mathrm{L}$ ratio in Burrowing Owl (Athene cunicularia). analyzed did not show any relation to the frequency of $\mathrm{MN}$ and $\mathrm{H} / \mathrm{L}$ index, however, it is considered that in diseased birds or pollution, both parameters would be altered. In this study, during the clinical evaluation of the birds, were healthy apparently for showing no signs of disease or injury. Martínez-Quintana et al. [4] suggest that to create the normal baseline parameters, is necessary a sample which preferably represents a broad demographic range of the species, so it is suggested to extend sampling in this owl species and other individuals of the Strigiforme order.

Our result, together with other studies with different species of owls, showed that members of Strigiformes Order are biomonitors acceptable for monitoring genotoxics agents, since species such as the Eastern Screech owl (Otus asio), Barn owl (Tyto alba) and the owl (Otus sp.) recorded acceptable $\mathrm{MN}$ frequencies [10,11].

In wild birds from disturbed areas with a persistence of contaminants, there tends to be an increase the frequency of $\mathrm{MN}$ in erythrocytes [24]. A similar effect was observed our study area, where in the Aguascalientes site, the frequency of MNE and NAE was higher than the rest of the sampling sites. Currently, this site transformations experiment from anthropic origin that endanger the quality of the habitat. Urban development through constructions for industrial purposes of automobile manufacture and logistic are the main cause, so that natural sites (grasslands and xerophilous scrub) are reduced. While El Llano site consists primarily of grassland patches and agricultural areas, human activity is often restricted to temporary agriculture and livestock farming (intensive and extensive).

It has been suggested to apply the $\mathrm{H} / \mathrm{L}$ ratio in conjunction with others parameters since by itself is difficult to differentiate between the types of acute and chronic stress [25]. For this reason, it is considered that the combination between the $\mathrm{H} / \mathrm{L}$ index and the $\mathrm{MN}$ test can give an approach to demonstrate the chronic exposure of the etiological agent. Biomonitoring of genotoxic pollutants in fragile habitats such as grasslands provides the guideline for timely corrective actions.

\section{Acknowledgement}

This research was carried out with the permission of scientific collector issued by the Secretaría of Medio Ambiente y Recursos Naturales (SEMARNAT: SGPA DGVS/08101/14). Thanks to Daga our Cooper hawk, for help in the capture of the owls, Idea Wild and MEDMAVIS team, too.

\section{References}

1. McFarland CN, Bendell-Young LI, Guglielmo C, Williams TD (2002) Kidney, liver and bone cadmium content in the western sandpiper in relation to migration. J Environ Monit 4:791-795.

2. Mallory ML, Robinson SA, Hebert CE, Forbes MR (2010) Seabirds as indicators of aquatic ecosystem conditions: A case for gathering multiple proxies of seabird health. Marine Poll Bull 60:7-12

3. Genovese K, Swaggerty HH, Kogut MH (2013) The avian heterophil. Dev Comp Immunol 41: 334-340.

4. Martínez-Quintanilla MC, Torres-Bugarín O, Martínez-Guerrero JH, DelgadoLeón TG, Salas-Pacheco JM et al. (2017) Relación heterófilo/linfocito, frecuencia espontánea de eritrocitos micronucleados y prolongaciones nucleares en el ganso nevado (Chen caerulescens): Una propuesta como posible biomonitor de estrés ygenotóxicos ambientales. Huitzil, Revista Mexicana de Ornitología 18:102-111.

5. van der ME, van Oers K (2015) Gender and personality differences in response to social stressors in Great Tits (Parus major). Plos One 10: e0127984.

6. Vleck CM, Vertalino N, Vleck D, Bucher TL (2000) Stress, corticosterone, and heterophil to lymphocyte ratios in free-living adélie penguins. The Condor 102 : 392-400.

7. Ramos-Remus C, Dorazco-Barragan G, Aceves-Avila FJ, Alcaraz-López F, Fuentes-Ramírez F, et al. (2002) Genotoxicity assessment using micronucle assay in rheumatoid arthritis patients. Clin Expe Rheumatol 20: 208-212. 
Citation: Martínez-Haro M, Balderas-Plata MA, Pereda-Solís ME, Arellano-Aguilar RO, Hernández-Millán CL, et al. (2017) Anthropogenic Influence on Blood Biomarkers of Stress and Genotoxicity of the Burrowing Owl (Athene Cunicularia). J Biodivers Endanger Species 5: 196. doi: $10.4172 / 2332-2543.1000196$

8. Rodríguez-Vázquez M., Sánchez-Ortiz A, Ramos-Remus C, Zuñiga G, TorresBugarín O (2000) Evaluación de la genotoxicidad de ciclofosfamida mediante prueba de micronúcleos en pacientes con lupus eritematoso sistémico. Rev Mex Reumatol 15: 41-45.

9. Heddle JA (1991) Implications for genetic toxicology of the chromosoma breakage syndromes. Mutat Res Fund Mol Mech Mut 247: 221-229

10. Zúñiga-González G, Torres-Bugarín O, Luna-Aguirre J, González-Rodríguez A, Zamora-Pérez A, et al. (2000) Spontaneous micronuclei in peripheral blood erythrocytes from 54 animal species (mammals, reptiles and birds): Part two. Mutat Res 467: 99-103.

11. Zúñiga-González G, Torres-Bugarín O, Zamora-Pérez A, Gómez-Meda BC Ramos-lbarra ML, et al. (2001) Differences in the number of micronucleated erythrocytes among young and adult animals including humans Spontaneous micronuclei in 43 species. Mutat Res 494:161-167.

12. Howell SNG, Webb S (1995) A guied to the birds of Mexico and Northerm Central America. Oxford University press, New York, USA p: 851

13. Gervais JA, Rosenberg DK, Comrack LA (2008) Burrowing owl (Athene cunicularia). In: California Bird Species of Special Concern: A ranked assessment of species, subspecies, and distinct populations of birds of immediate conservation concern in California. Shuford WD, Gardali T (editors) Studies of Western Birds 1. Western Field Ornithologists, Camarillo, California, and California Department of Fish and Game, Sacramento, California, USA.

14. Sibley DA (2014) The Sibley guide to birds. Scott and Nix Inc NY, USA p: 598.

15. McDonald D, Korfanta NM, Lantz SJ (2004) The burrowing owl (Athene cunicularia): A technical conservation assessment. USDA Forest Service, Rocky Mountain region.

16. INEGI (2009) Instituto Nacional de Estadística y Geografía. México. Prontuario de información geográfica municipal de los Estados Unidos Mexicanos: El Llano, Aguascalientes.

17. INEGI (2009) Instituto Nacional de Estadística y Geografía. México. Prontuario de información geográfica municipal de los Estados Unidos Mexicanos: Aguascalientes, Aguascalientes.

18. INEGI (2009) Instituto Nacional de Estadística y Geografía. México. Prontuario de información geográfica municipal de los Estados Unidos Mexicanos: Asientos, Aguascalientes.

19. Svensson L (1996) Guía de identificación de los Paseriformes de Europa. SEOBirdlife. Madrid, España p: 404.

20. Kursa M, Bezrukov V (2007) Health Status in an Antarctic Top Predator: Micronuclei Frequency and White Blood Cell Differentials in the South Polar Skua (Catharacta maccormicki). Polarforschung 77: 1-5.

21. Ahmad K, Saleh J (2010) Clastogenic studies on Tandaha Dam water in Asser J Black Sea/Mediterranean Environment 16: 33-42.

22. Miller MJR, Wayland ME, Bortolotti GR (2001) Hemograms for and nutritional condition of migrant bald Eagles tested for exposure to lead. J Wildlife Dis 37: 481-488.

23. Hanauska-Brown LA, Dufty AM, Roloff GJ (2003) Blood chemistry, cytology, and body condition in adult northern goshawks (Accipiter gentilis). J Raptor Res 37:299-306.

24. Baesse $C Q$, de Magalhães Tolentino VC, da Silva AM, de Andrade Silva A Ferreira GÂ, et al. (2015) Micronucleus as biomarker of genotoxicity in birds from Brazilian Cerrado. Ecotoxicol Environ Saf 115: 223-228.

25. Cotter PF (2015) An examination of the utility of heterophil-limphocyte ratios in assessing stress of caged hens. Poultry Sci 94:512-517. 